\title{
Targeted disruption of the pituitary glycoprotein hormone $\alpha$-subunit produces hypogonadal and hypothyroid mice
}

\author{
Susan K. Kendall, ${ }^{1,2}$ Linda C. Samuelson, ${ }^{1,3}$ Thomas L. Saunders, ${ }^{2}$ Ruth I. Wood, ${ }^{4}$ \\ and Sally A. Camper ${ }^{1,2}$ \\ ${ }^{1}$ Cell and Molecular Biology Program and Departments of ${ }^{2}$ Human Genetics and ${ }^{3}$ Physiology, University of Michigan \\ Medical School, Ann Arbor, Michigan 48109-0618 USA; ${ }^{4}$ Department of Obstetrics and Gynecology, Yale University School \\ of Medicine, New Haven, Connecticut 06520-8063 USA
}

Pituitary thyrotropin (TSH) and gonadotropins ( $\mathrm{LH}$ and FSH) are thought to be critical for thyroid and gonadal development and function. Each of these pituitary hormones is a heterodimer composed of a common $\alpha$-subunit and unique $\beta$-subunit, and heterodimerization is required for function. No mutations in the $\alpha$-subunit or any of the $\beta$-subunit genes have been reported in mice. To assess directly the functional role of TSH, LH, and FSH in thyroid and gonadal development, we created a disruption of the $\alpha$-subunit gene by homologous recombination. The homozygous mutant animals were hypogonadal and exhibited profound hypothyroidism resulting in dwarfism. Thyroid development was arrested in late gestation, but GnRH neuron migration, development of secondary sex organs, and fetal and neonatal gonadal development were normal. This establishes the importance of thyrotropin in ontogeny and reveals that fetal pituitary gonadotropins are not required for sexual differentiation or genital development in male or female fetuses. The pituitary cells that produce TSH $\beta$-subunit exhibited dramatic hypertrophy and hyperplasia as a result of the lack of thyroid function. This proliferative response occurred at the expense of somatotrope and lactotrope cells, consistent with a derivation of these three cell types from a common precursor.

[Key Words: $\alpha$-Subunit, pituitary glycoprotein hormone; hypogonadism; hypothyroidism; gene targeting; GnRH neurons]

Received May 16, 1995; revised version accepted July 6, 1995.

The anterior and intermediate lobes of the pituitary gland develop from a pocket of oral ectoderm known as Rathke's pouch. At $\sim$ E11.5 (embryonic day 11.5) in the fetal rat, the cells of Rathke's pouch invaginate toward the diencephalon and the developing hypothalamus. At the same time the floor of the diencephalon evaginates toward Rathke's pouch. These neural ectoderm-derived cells of the diencephalon eventually form the posterior pituitary lobe and remain connected to the hypothalamus by the pituitary stalk. Rathke's pouch gradually closes and becomes detached from the epithelium of the palate (Schwind 1928). Differentiation and growth of the hypothalamic anlage and of Rathke's pouch depend on their mutual contact, suggesting that each exerts local inductive influences (Daikoku et al. 1982, 1983). The nature of these influences remains to be determined.

One of the first molecular markers for the developing pituitary gland is the $\alpha$-subunit common to the heterodimeric pituitary glycoprotein hormones thyroidstimulating hormone (TSH), luteinizing hormone (LH), and follicle-stimulating hormone (FSH). It is expressed in the placode that becomes Rathke's pouch several days before the TSH $\beta$-, LH $\beta-$, and FSH $\beta$-subunits, suggesting that it may play a role apart from its role as a subunit of these hormones. The $\alpha$-subunit, unlike the $\beta$-subunits, can be secreted as a monomer, and it exhibits a different glycosylation pattern from the $\alpha$-subunit complexed with a $\beta$-subunit (Baenziger and Green 1991). The crystal structure of $\alpha$-subunit reveals that its tertiary structure is a cystine knot formed by three disulfide bridges. This motif is shared by the glycoprotein hormone $\beta$-subunits and by three growth factors: nerve growth factor (NGF), transforming growth factor (TGF)- $\beta 2$, and platelet-derived growth factor (PDGF)-BB, suggesting that free $\alpha$-subunit may have some growth factor activity (Lapthorn et al. 1994). Although no receptor for $\alpha$-subunit has been identified, biological activity of the free $\alpha$-subunit is suggested by its ability to induce both lactotrope differentiation (Begeot et al. 1984) and prolactin (PRL) secretion (Blithe et al. 1991). Although these results suggest an inductive role for free $\alpha$-subunit, its function must be tested in vivo.

The hypothalamic neurons that produce gonadotropin-releasing hormone (GnRH) have an unusual developmental history in that they originate from extraneuronal tissue in the olfactory placode and migrate during 
prenatal development along the nervus terminalis to reach the preoptic area and hypothalamus (Wray et al. 1989). In recent years, investigators have examined the signals that guide migration of $\mathrm{GnRH}$ neuroblasts and the targeting of their axons to the median eminence (for review, see Schwanzel-Fukuda et al. 1992). One plausible hypothesis was that signals from the pituitary might aid this process, either stimulating movement of $\mathrm{GnRH}$ cells themselves, or guiding the extension of their axons caudally to the median eminence. This hypothesis was supported by observations that GnRH neurons from the preoptic area grown in roller cultures will extend processes preferentially toward pituitary cultures (Wray et al. 1988). If the chemotaxic signal is produced by the developing pituitary gland, the cells that respond to $\mathrm{GnRH}$, the gonadotropes, would be a logical source. Because the $\alpha$-subunit is expressed at E11.5 in Rathke's pouch in the rat (Simmons et al. 1990), before GnRH neuron migration begins, it is a good candidate for the chemotactic signal.

$\alpha$-Subunit expression is not restricted to Rathke's pouch during development. Transcripts are also present in the region outside of the olfactory placode and in the extraocular region in mouse embryos (Kendall et al. 1994). A functional role for $\alpha$-subunit expression in these extrapituitary regions has yet to be established.
No known mutations in the $\alpha$-subunit, TSH $\beta$-, FSH $\beta$-, or LH $\beta$-subunit genes have been identified in the mouse. To assess the developmental roles of free $\alpha$-subunit and fetal TSH, LH, and FSH in vivo, we created mice lacking functional $\alpha$-subunit by targeted disruption of the gene in embryonic stem (ES) cells.

\section{Results \\ Targeted disruption of the pituitary glycoprotein hormone $\alpha$-subunit}

The mouse pituitary glycoprotein hormone $\alpha$-subunit gene consists of 4 exons and spans $\sim 13.5 \mathrm{~kb}$. The coding region of the 96-amino-acid protein is contained within exons 2, 3, and 4 (Gordon et al. 1988). A targeting vector was constructed containing the neomycin resistance gene (neo) inserted within the third exon and the herpes simplex virus (HSV) thymidine kinase gene at the 3 ' end (Fig. 1A). ES cells were electroporated with the targeting vector and selection was carried out with both G418 and gancyclovir. Four homologous recombinants were detected by PCR on DNA from 880 individual doubly selected clones (Fig. 1B). The integrity of these four homologous recombinants was confirmed by Southern blot analysis of the $5^{\prime}$ and $3^{\prime}$ ends of the gene using several

A

Mouse $\alpha$-subunit gene:
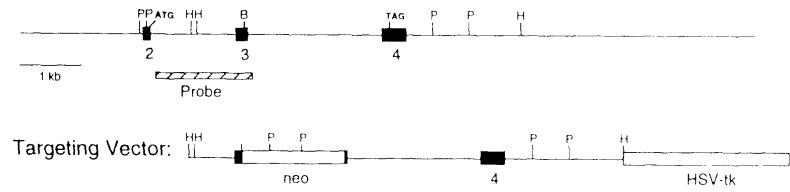

Homologous Recombinant:

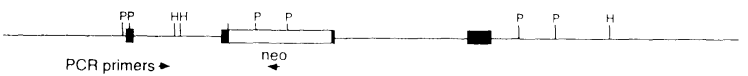

Control plasmid:

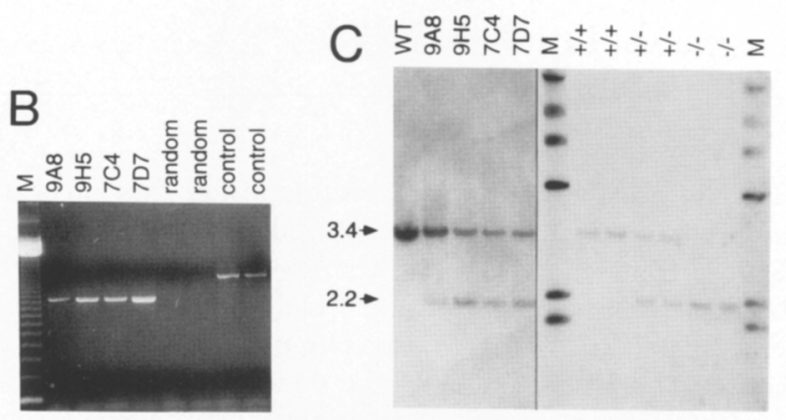

Figure 1. Targeted disruption of the pituitary glycoprotein hormone $\alpha$-subunit gene. $(A)$ The targeting vector contained $4 \mathrm{~kb}$ of $\alpha$-subunit homologous sequences, including exons 3 and 4 and $3^{\prime}$ flanking sequences. The third exon was disrupted at a BalI site (B) in the region encoding amino acids 65 and 66, by a neomycin cassette. Amino acids in both the 33 and 45 positions (within exon 3 ) and at the carboxyl terminus have been shown to be important for biological function (Chen et al. 1993; Xia et al. 1994). Thus, transcripts that are spliced from exon 2 to exon 4 or terminate within exon 3 would not produce functional protein. An HSV-tk cassette was joined to the end of the largest homologous region. Both cassettes contained the phosphoglycerokinase (PGK) promoter and poly(A) sequences and were placed in the opposite transcriptional orientation to that of the mouse $\alpha$-subunit gene. The PCR primers used to screen for homologous recombinants are shown (arrows) with the predicted structure of the gene after homologous recombination. A plasmid used as a positive control for the PCR reactions included $\alpha$-subunit sequences upstream of the targeting vector and the neomycin cassette inserted downstream of exon 3. PCR amplification of this control plasmid produced a slightly larger product than the homologous recombinant. (P), PvuII; (H), HindIII. (B) Four ES clones $(9 \mathrm{~A} 8,9 \mathrm{H} 5,7 \mathrm{C} 4$, and 7D7) were identified as homologous recombinants by PCR screen using the primers shown in $A$. Amplification products of $1.1 \mathrm{~kb}$ and $1.7 \mathrm{~kb}$ were obtained from homologous recombinants and the control plasmid, respectively. No amplification was detected in randomly selected G418-resistant clones. A 123-bp ladder served as a molecular weight marker (M). (C) Genomic DNA from wild-type ES cells (WT) and the four ES clones was digested with PvuII and analyzed by Southern blotting. Hybridization with a fragment of the mouse $\alpha$-subunit gene (see $A$, probe) revealed the expected $3.4 \mathrm{~kb}$ and $2.2 \mathrm{~kb}$ fragments from the endogenous and disrupted alleles, respectively. Chimeras produced with the $7 \mathrm{C} 4$ clone gave germ-line transmission. These heterozygotes were intercrossed and the genotypes of the progeny were determined by Southern blot of tail DNA. $\lambda$ DNA digested with HindIII served as the molecular weight marker (M). 
different probes and DNA digested with seven different restriction enzymes (Fig. 1C; data not shown). Two clones had a normal chromosome number and were injected into C57BL/ 6 blastocysts. Chimeras were bred to C57BL/6 mice, and germ-line transmission of the disrupted $\alpha$-subunit gene was obtained with one clone (7C4).

\section{$\alpha$-Subunit - / - animals are viable but exhibit growth insufficiency}

Heterozygotes were intercrossed to obtain homozygotes for the $\alpha$-subunit disruption. Litter sizes averaged eight pups, indicating normal fertility of both male and female heterozygotes. The ratio of genotypes represented at 2-3 weeks of age did not deviate significantly from the expected 1:2:1 distribution, and equal proportions of male and female homozygotes were obtained. This indicates that lack of $\alpha$-subunit does not affect viability. Although the -1 - animals were indistinguishable from their littermates at birth, they exhibited severe growth insufficiency. By 4.5 weeks of age, $-/-$ mice were approximately half the size of their normal littermates (Fig. 2A). Weight measurements demonstrated that the reduced growth of $-1-$ animals is evident between 2 and 3 weeks of age (Fig. 2B).

\section{$\alpha$-Subunit - / - animals are hypothyroid and hypogonadal}

The reduced growth of the $-/-$ animals was consistent with TSH-deficient hypothyroidism (Beamer et al. 1981). Hypothyroidism was confirmed by serum radioimmunoassay (RIA) measurements of total and free thyroxine $\left(\mathrm{T}_{4}\right)$ produced by the thyroid in response to TSH stimulation. Total $\mathrm{T}_{4}$ in serum from $-/$ - animals was undetectable. Free $\mathrm{T}_{4}$, the biologically active form of $\mathrm{T}_{4}$, was also below the lower limit of the standard curve $\mid<0.2$ $\mathrm{ng} / \mathrm{dl}$ ), whereas levels in $+/+$ and $+/$ - animals were $1.9 \pm 0.33$ and $2.0 \pm 0.39 \mathrm{ng} / \mathrm{dl}$, respectively (Fig. 3A). The size of the thyroid follicles and height of follicular epithelium are indicators of normal thyroid development and function (Fig. 3B). Histological examination of thyroids from $-/$ - animals revealed undersized and underdeveloped glands containing small, disorganized follicles (Fig. 3C).

Normal male mice usually grow $\sim 20 \%$ larger than females because of the influence of testosterone (Fig. 2B). There were no gender differences in the size of $-1-$ animals at any age. In addition, $-/-$ mice exhibited infertility, prepubertal external genitalia, and in females, failure of the vaginal orifice to open. These results indicated a lack of sex steroids in the $-/-$ animals, which was confirmed in males with testosterone measurements. Testosterone RIA was performed on serum pooled from six $-/-$ and six $+/+$ male adult animals. Although $+/+$ males had testosterone levels of $4.17 \pm 0.29 \mathrm{ng} / \mathrm{ml}$, testosterone levels in $-/-$ males were below $0.1 \mathrm{ng} / \mathrm{ml}$, the limit of detection of the assay.

Examination of the gonads of $-1-$ animals revealed lack of development and function. The testes of 8-week-
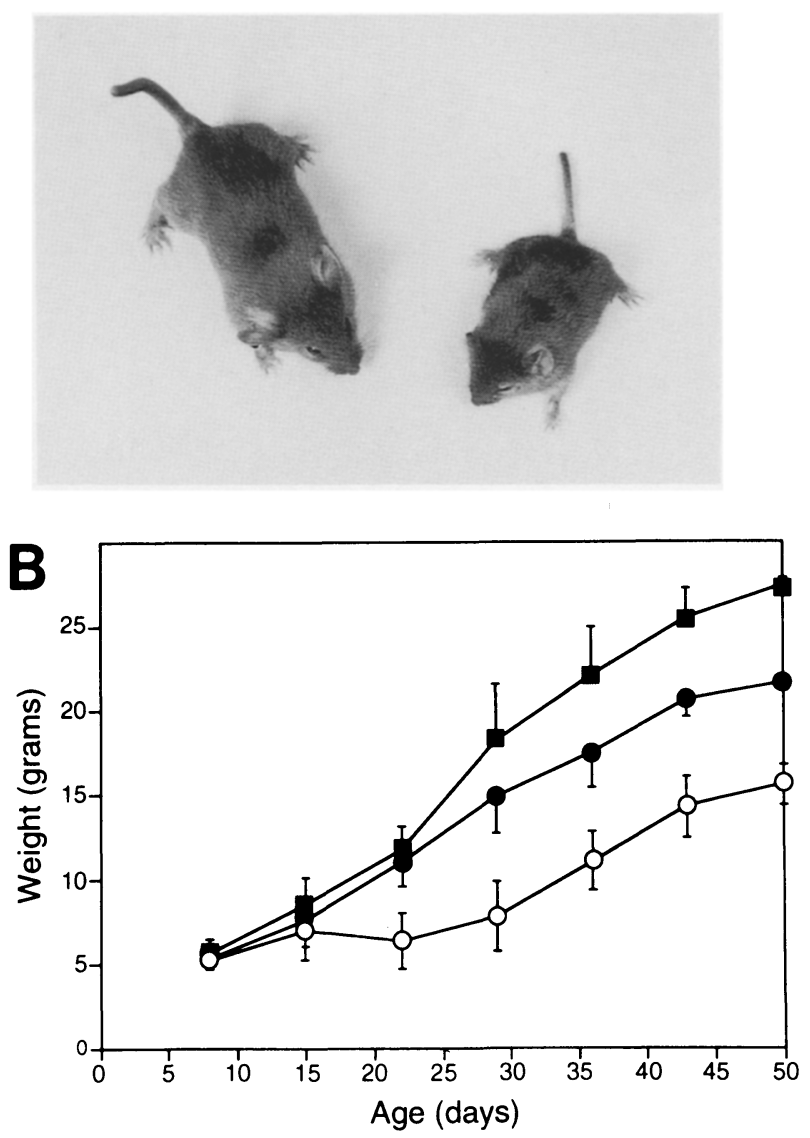

Figure 2. Proportionate dwarfism of $\alpha$-subunit $-/$ - animals. At 4.5 weeks of age, an $\alpha$-subunit $-/-$ mouse $(A$, right $)$ was $\sim 50 \%$ smaller than its $+/+$ littermate $(A$, left $)$. The growth of -1 - animals $(B, O)$ was similar to control $+1+$ and $+1-$ females $(O)$ and males ( $\square$ ) until 2-3 weeks of age (for days 8-43, $n=5-24)$.

old $-/$ - animals were severely reduced in size (Fig. 4A). In males, the epididymis and vas deferens were present, providing evidence of complete male sexual differentiation. However, seminal vesicles were not readily visible, consistent with testosterone deficiency. Histological sections of 8-week-old $+/+$ testes demonstrated the presence of sperm at various stages of development, including mature sperm within the lumen of the seminiferous tubules (Fig. 4C). Sections of $-1-$ testes revealed smaller seminiferous tubules, scanty interstitial cells, and spermatogenesis blocked at the first meiotic division (Fig. 4E). The appearance of the seminiferous tubules in 8-week-old $-/-$ testes suggests that they did not develop significantly beyond birth. Testes from $-/-$ neonatal animals had undeveloped tubules (Fig. 4G) and appeared exactly like testes of $+/+$ neonatal animals (data not shown). Thus, testis development proceeded normally during the fetal period.

Sexual differentiation also occurred normally in $-/-$ females, but ovaries were very small and uteri were thread-like (Fig. 4B). The uteri were less developed than uteri of normal immature 3-week-old animals, indicating that the $-/-$ mice lack estrogen. Follicles within 

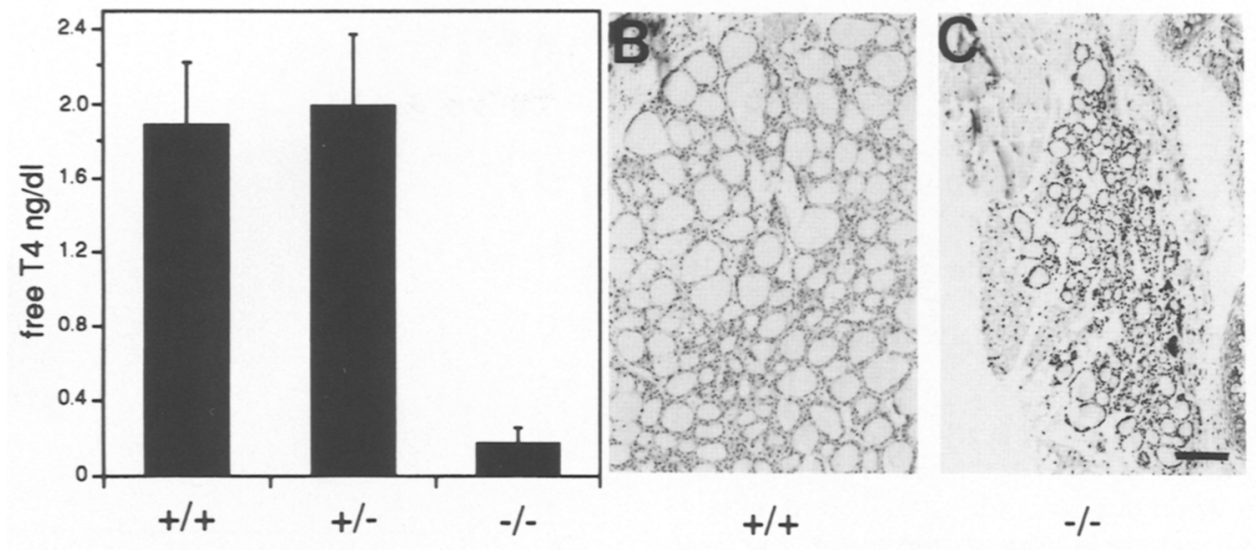

Figure 3. $\alpha$-Subunit -1 - animals are hypothyroid. Free thyroxine $\left(\mathrm{T}_{4}\right)$ in serum was measured by RIA in samples from four animals of each group $(A)$. Histology performed on hematoxylin and eosin-stained paraffin sections revealed the lack of thyroid development in $-I$ - animals $(n=2, C)$ compared with $+1+$ controls $\langle B|$. Both $B$ and $C$ are at the same magnification; Bar, $100 \mu \mathrm{m}$.

the ovaries of $-1-$ animals exhibited limited development. A normal 8-week-old $+1+$ ovary contained follicles at varying developmental stages. Follicles at the antral stage and corpora lutea were noted (Fig. 4D). Follicles in 8-week-old - / - ovaries displayed considerable development but remained small, did not progress to the antral stage, and did not produce corpora lutea (Fig 4F). This indicated the absence of ovulation and contributed to the much smaller size of the organ. In contrast, the ovaries from both neonatal $-1-$ and $+1+$ animals contained no recognizable follicles (Fig. $4 \mathrm{H}$ ) and were indistinguishable from each other (data not shown). Thus, ovarian development in $-/$ - animals continued in the postnatal period, but was arrested before postnatal day 21 when antral follicles normally first appear (Jones 1978).

\section{Altered cell makeup of - / - anterior pituitaries}

Pituitary glands from -1 - mice were slightly larger than $+1+$ littermate pituitaries at 8 weeks. The architecture of the pituitaries was normal, consisting of the posterior, intermediate, and anterior lobes. The $-1-$ pituitaries were far less granular than normal pituitaries. The $\alpha$-subunit protein was not detectable by immunocytochemistry in pituitary sections from $-/-$ animals (Fig. 5E), although it was abundant in both $+1+$ and $+/-$ pituitary sections (Fig. 5A). An abundance of hypertrophic thyrotropes were visible throughout the $-/$ pituitaries (Fig. 5C). The intense staining of these cells for TSH $\beta$-subunit is consistent with the retention of TSH $\beta$-subunit in $\alpha$-subunit-deficient thyrotropes. The thyrotropes also exhibited dramatic hyperplasia, becoming the most numerous cells in the $-1-$ pituitaries. In contrast, thyrotropes make up only $2 \%-5 \%$ of the anterior pituitary cells in normal adult mice (Fig. 5B). The thyrotrope hypertrophy and hyperplasia in $-1-$ pituitaries was compared to that resulting from thyroid failure induced in normal adult mice. Treatment with radioactive iodine resulted in discrete foci of enlarged thyrotrope cells that rapidly secrete TSH $\beta$-subunit (Fig. 5D).
In contrast to the advanced, diffuse hyperplasia evident in 2-month-old - 1 - animals, the thyrotrope hyperplasia remained nodular 8 months after radiothyroidectomy.

To determine the developmental profile of the thyrotrope hypertrophy and hyperplasia, pituitaries from $-/$ - mice at birth, 3 weeks, and 6 months were stained for TSH $\beta$-subunit. At birth, thyrotropes were normal size in $-/-$ animals (Fig. 5F). At 3 weeks of age, some enlargement of the pituitary was noted in three of five $-/$ - mice at autopsy (data not shown). Thyrotrope hypertrophy was noted even in mice that had not yet developed obvious pituitary hyperplasia. At 6 months of age, the pituitary gland in $-1-$ animals had increased to approximately three to four times the size of normal glands. Hyperplasia of thyrotropes was also more extensive. Normal cell types were found predominately at the periphery of the gland (data not shown).

Gonadotropes were present in - / - pituitaries in normal proportions and exhibited little or no hypertrophy at 2 months (Fig. 5G,H,L,M) or 6 months (data not shown). This was demonstrated by staining for both LH $\beta$-subunit and $\mathrm{FSH} \beta$-subunit since the majority of gonadotropes produce both of these hormones (Pelletier et al. 1976; Childs and Ellison 1980|. Neither the proportion nor the appearance of the cells producing adrenocorticotropic hormone (ACTH) was affected by the lack of $\alpha$-subunit (Fig. 5K,P).

Changes in anterior pituitary cell types that do not produce $\alpha$-subunit were noted. The number of growth hormone-producing cells (somatotropes) was reduced dramatically in $-/-$ animals (Fig. 5I,N). The PRL-producing cells were nearly absent. No lactotropes were detectable in male $-/-$ pituitaries, although a few rare cells could be detected in females (Fig. 5J,O).

\section{Absence of $\alpha$-subunit transcripts in - / - pituitaries}

We confirmed that the targeting vector effectively disrupted transcription of the $\alpha$-subunit gene by in situ hybridization (Fig. 6) and RT-PCR (data not shown). No 

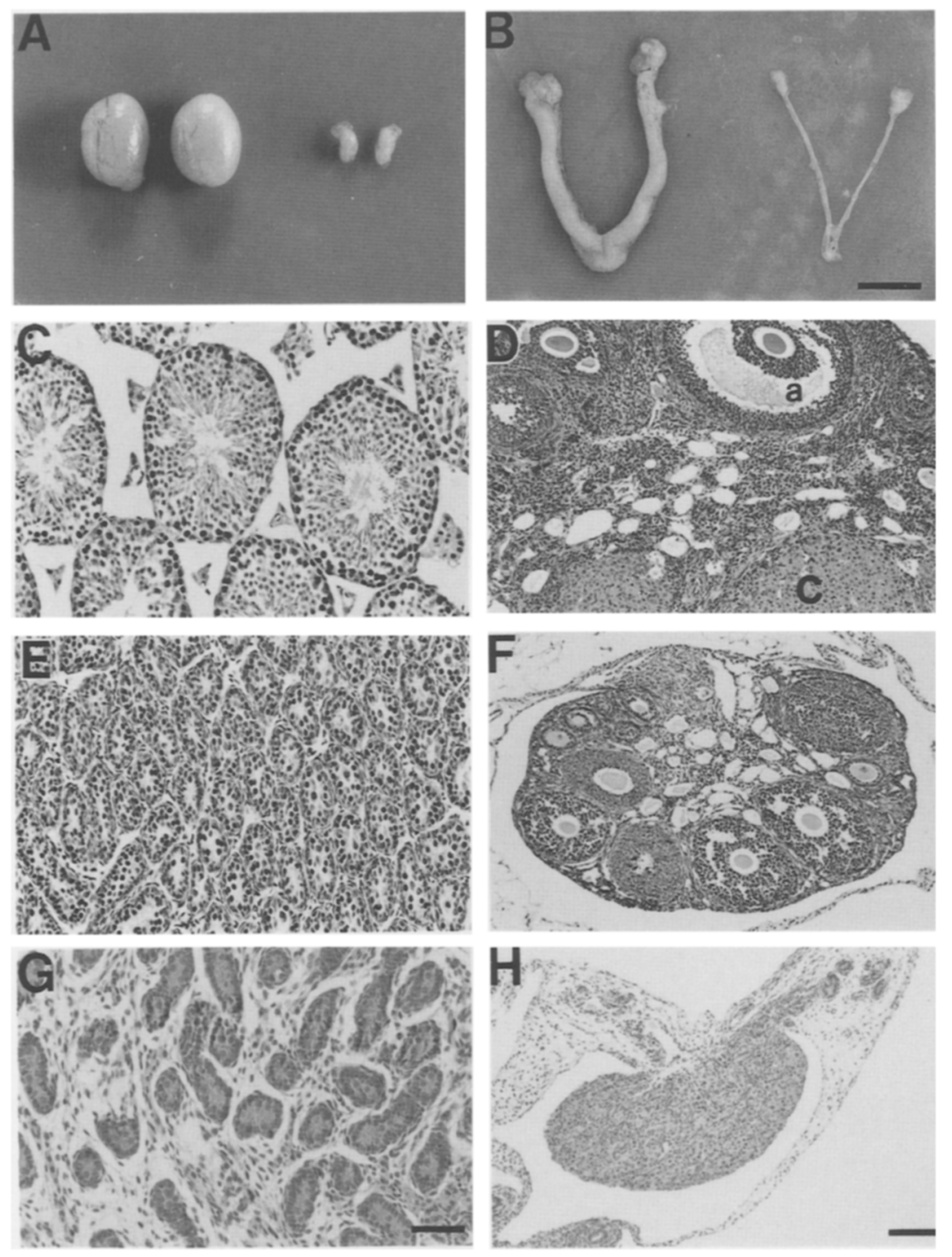

Figure 4. $\alpha$-Subunit $-/$ - animals exhibit primary sexual differentiation but reduced gonadal development. At 8 weeks, male $(A)$ and female $(B)$ mutants $-/-($ right) exhibited severe hypogonadism relative to controls $+/+$ (left). Paraffin sections of ovaries or testes were stained with hematoxylin and eosin $(C-H)$. Normal 8-week-old control testes contain mature sperm $(C)$, but no sperm development was evident in $-/-$ testes $(n=2, E)$. Testes from 1-day-old $-1-(G)$ and $+1+$ animals (not shown) were indistinguishable. Ovaries from 8-week-old $+/+$ animals $(n=2, D)$ contained corpora lutea (c) and follicles at various stages of antrum (a) formation. Only preantral follicles were present in $-/-$ ovaries $(F)$. Ovaries from 1-day-old $-/-(H)$ and $+/+$ (not shown) animals were indistinguishable. $(A, B) \mathrm{Bar}, 5$ $\mathrm{mm}_{;}(C, E, G)$ bar, $50 \mu \mathrm{m} ;(D, F, H)$ bar, $100 \mu \mathrm{m}$. $\alpha$-subunit transcripts were detectable in pituitaries of male or female - / - mice, although transcripts were abundant in normal pituitary glands. TSH $\beta$-subunit transcripts were readily detected by in situ hybridization in sections from the same glands. The $-/-$ mice had considerably higher levels of TSH $\beta$-subunit transcripts than in normal mice. No $\alpha$-subunit transcripts were detected in $-/-$ pituitaries by RT-PCR using two sets of primers. One set of primers was designed to anneal within exons 2 and 4 to detect cDNA transcripts resulting from skipping exon 3 . To identify truncated transcripts, another primer set was designed within exon 2 and $5^{\prime}$ to the neo cassette in exon 3. Normal $\alpha$-subunit transcripts were detected with both of these primers in $+1+$ and $+/-$ pituitaries, but no transcripts were evident in $-1-$ pituitaries by ethidium bromide staining of amplified products $(n=4)$. Very low levels of truncated and exon-skipped transcripts were detected in $-/-$ pituitary RNA using radiolabeled primers. These rare aberrant transcripts would not be expected to make func- tional protein because the folded tertiary structure of the $\alpha$-subunit protein is crucial for binding to both $\beta$-subunit and receptor (Lapthorn et al. 1994). Secretion of the $\beta$-subunits cannot occur without heterodimerization with the $\alpha$-subunit (Corless et al. 1987; Matzuk et al. 1988, 1989; Keene et al. 1989). Thus, the targeted disruption created a true null mutation for functional $\alpha$-subunit in addition to the hormones TSH, LH, and FSH.

\section{Distribution of GnRH neurons and $G n R H$ immunoreactivity in $\alpha$-subunit - / - mice}

The possibility that free $\alpha$-subunit might serve as a homing signal for GnRH neuron migration to the hypothalamus during development was tested by comparing the location of GnRH neurons and fibers in $+1+$ and $-1-$ mice (Fig. 7). The distribution of immunoreactive GnRH neurons and fibers in $+1+$ mice was equivalent to that described previously (Hoffman et al. 1978). GnRH neu- 


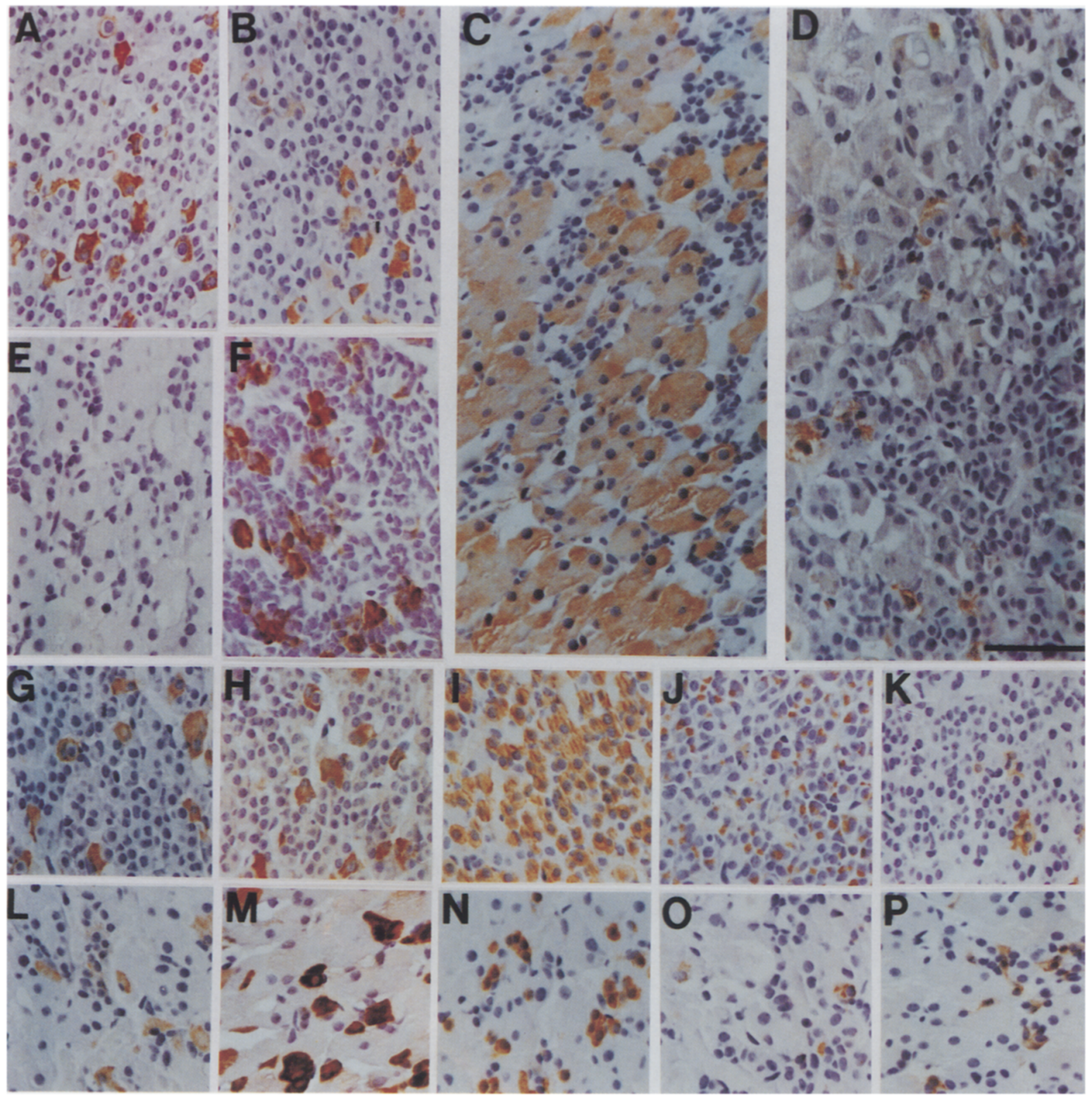

Figure 5. The proportion of specialized anterior pituitary cells types is altered in $\alpha$-subunit - / - animals. Pituitary sections from $+1+$ and $-1-$ animals $(n=3)$ were immunostained with pituitary hormone antibodies, and counterstained with hematoxylin and eosin. All sections shown are from 8-week-old male animals unless specified otherwise. Cells producing the $\alpha$-subunit were detected in $+/+(A)$ but not $-/-(E)$ mice, although TSH $\beta$-subunit staining is evident in both $+/+(B)$ and $-/-(C)$ mice. Discrete foci of hypertrophic thyrotropes are present in radiothyroidectomized mice $(\sim 7$ months old, $D)$. TSH $\beta$-subunit staining revealed neither hypertrophy nor hyperplasia in 1-day-old - / - animals $(F)$. LH $\beta$-subunit $(G, L)$ and FSH $\beta$-subunit $(H, M)$ staining demonstrated that the size and number of gonadotropes was comparable in $-/-(L, M)$ and $+/+(G, H)$ mice. Growth hormone-producing cells were reduced in $-/-(N)$ relative to $+1+(I)$ mice. Although lactotropes were abundant in $+/+$ pituitaries, especially females $(J)$, very few lactotropes cells could be detected in $-/$ - females $(O)$. ACTH immunostaining was similar in $-/-(P)$ and $+/+$ controls $(K)$. Bar, $50 \mu \mathrm{m}$.

rons were scattered from tenia tecta rostrally to the mediobasal hypothalamus, with the largest number of stained neurons visible in the diagonal band of Broca and preoptic area. As expected, some GnRH neurons were also visible in the hypothalamus or outside midline nuclei, most often in the bed nucleus of the stria terminalis and lateral hypothalamus. GnRH immunoreactive fibers extended from the third ventricle to the arcuate nucleus and to the median eminence. Beaded varicosities from $\mathrm{GnRH}$ fibers were visible in the median eminence, where the neurohormone is released into the portal vasculature (Fig. 7D). Immunostained fibers extended cau- 

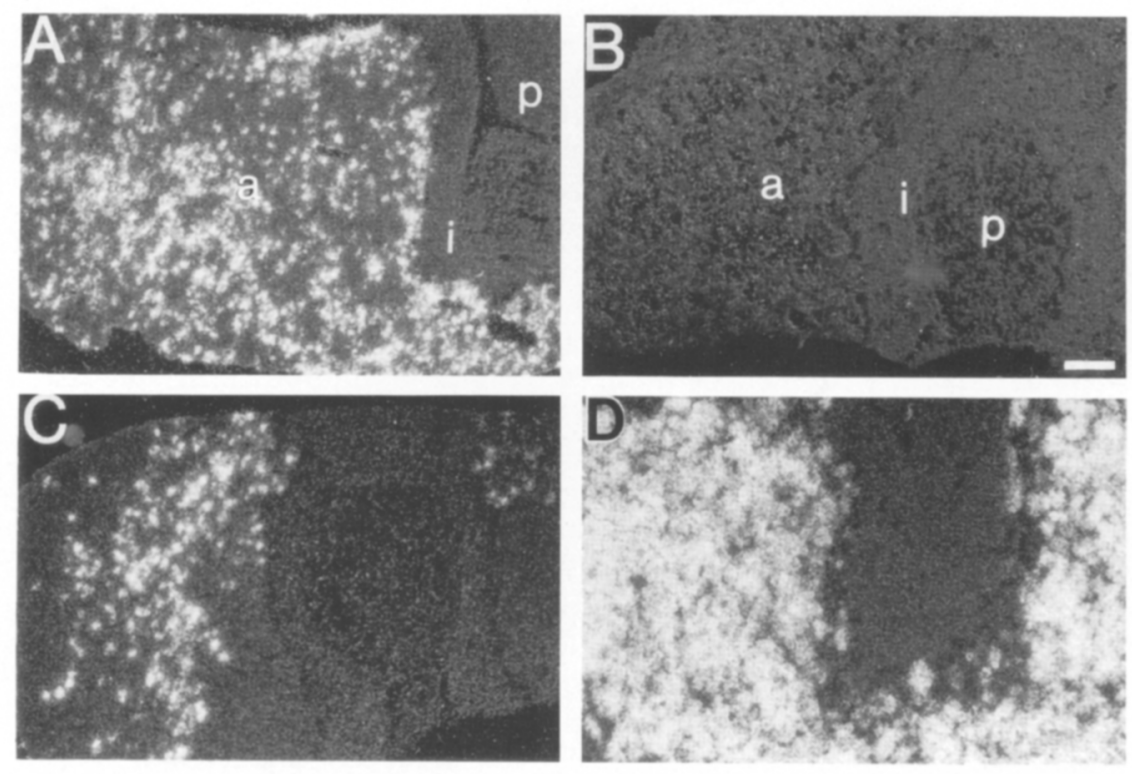

Figure 6. In situ hybridization confirmed the absence of $\alpha$-subunit mRNA and elevated TSH $\beta$-subunit mRNA in - / - pituitaries. In situ hybridization was performed with $\alpha$-subunit $(A, B)$ or TSH $\beta$-subunit $(C, D)$ cDNA antisense riboprobes on frozen pituitary sections from $+/+(A, C)$ and $-1-(B, D)$ mice. Sections were dipped in emulsion, exposed for 1 week, and photographed in dark field. (a) Anterior; (i) intermediate; (p) posterior lobes. Bar, $200 \mu \mathrm{m}$. dally from the preoptic area in two bundles, one along the third ventricle and the other dorsal to the optic tracts. The distribution of GnRH neurons and appearance of immunoreactive fibers in the $\alpha$-subunit $-1-$ animals was indistinguishable to that observed in $+1+$ animals.

\section{Discussion}

The hypothyroid and hypogonadal phenotype obtained when the $\alpha$-subunit gene is disrupted results primarily from the lack of the three hormones TSH, LH, and FSH. We confirmed that the $\alpha$-subunit disruption produced a null allele by in situ hybridization, RT-PCR, and immunocytochemistry for $\alpha$-subunit. TSH $\beta$-, FSH $\beta$-, and LH $\beta$ - subunits are not secreted in the absence of $\alpha$-subunit. Therefore, $\alpha$-subunit-deficient mice cannot produce or secrete biologically active TSH, LH, or FSH. The absence of these hormones arrested thyroid development late in gestation and gonadal development several weeks after birth.

\section{Fetal thyroid and gonadal development} in the absence of TSH, LH, and FSH

In the absence of both $\mathrm{LH}$ and $\mathrm{FSH}$, complete sexual differentiation and fetal genital development occurred normally. Both epididymis and vas deferens were present in $-1-$ males on the day of birth. The differentiation of these structures from the Wolffian duct is testosterone

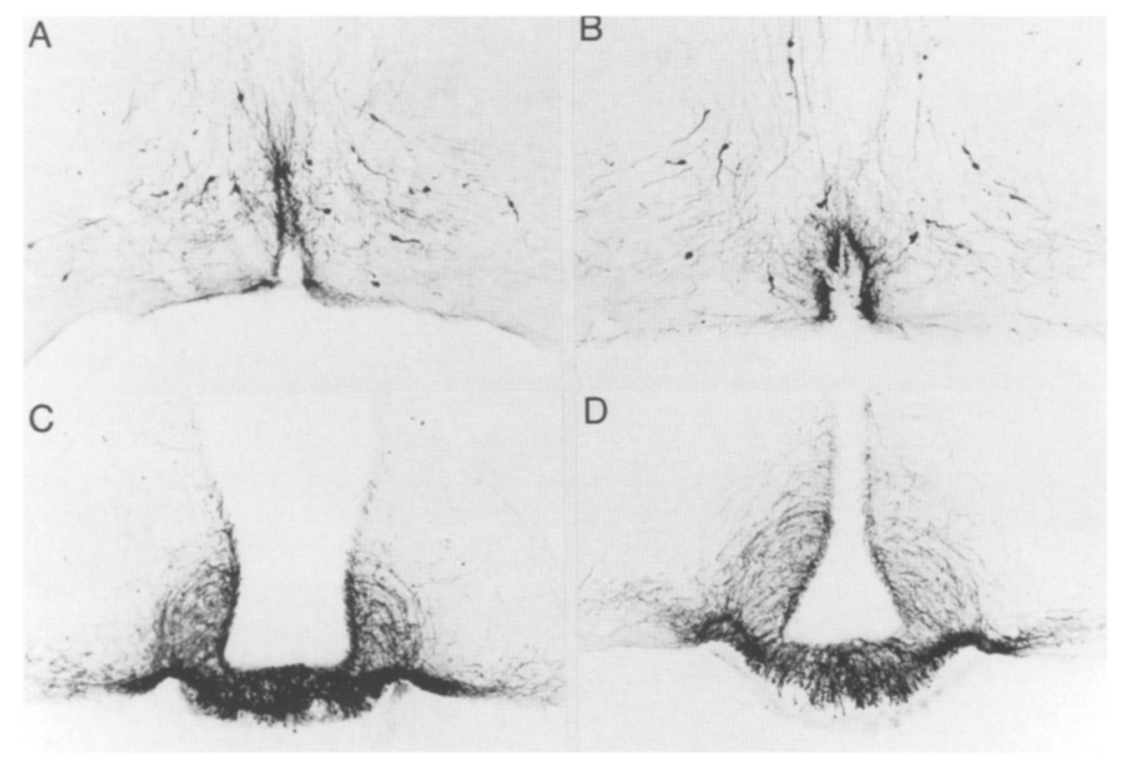

Figure 7. GnRH neuroanatomy is normal in $\alpha$-subunit $-/$ - mouse brains. GnRH immunoreactive neurons (top) and fibers (bottom) were indistinguishable in $-1-(A, C)$ and $+/+(B, D)$ brains. GnRH neurons were most abundant in the preoptic area (top). Immunostained fibers extended across the arcuate nucleus from the third ventricle to the ventral surface of the brain, and into the median eminence (bottom). 
dependent (Desjardins 1981). The presence of the epididymis and vas deferens indicates that the $-/-$ mice were capable of producing sufficient levels of testosterone during fetal development in spite of the lack of detectable testosterone in - / - adults. Testosterone secretion by the Leydig cells is stimulated by pituitary LH in adult animals. Several pieces of evidence suggested that fetal testosterone secretion requires very little if any LH stimulation. Wolffian duct differentiation occurs between E12.5 and E14.5 in mice (Price and Ortiz 1965), but LHß transcription is not detected until E16 (Japon et al. 1994). In addition, mice with a deletion of the GnRH gene, the hpg mutation, have low gonadotropin levels but complete sexual differentiation (Cattanach et al. 1977). However, the possibility existed that low levels of $\mathrm{LH}$ could exert a significant effect on testosterone production. The $\alpha$-subunit $-/-$ mice provide the most conclusive evidence that fetal testosterone secretion does not require the stimulatory effects of pituitary $\mathrm{LH}$ in rodents.

Two human mutations also address the question of the importance of LH in fetal development. A mutation in the $\mathrm{LH}$ receptor produced pseudohermaphrodites with testes and normal Wolffian duct derivatives, but few germ cells (Kremer et al. 1995). This phenotype is consistent with the idea that the testosterone necessary for Wolffian duct virilization is produced independently of fetal pituitary input. However, the patients did not develop male external genitalia. Apparently, in humans, male genital development requires $\mathrm{LH}$ receptor function in Leydig cells to promote androgen biosynthesis, whereas in mice the phenotype of the $\alpha$-subunit - / males demonstrated that $\mathrm{LH}$ is not required for genital development. The idea that there is a species difference in the requirement for $\mathrm{LH}$ is supported by the finding that the timing of complete male sexual differentiation is condensed in mice compared with humans. Wolffian duct virilization and development of external genitalia both occur within only a few days in the mouse fetus; thus, initial secretion of androgens may be sufficient for both processes to occur independently of pituitary input. In contrast, in human fetuses, these two processes take place over 20-30 days (Hamilton and Mossman 1972). However, a mutation in the LH $\beta$-subunit gene in a human family had consequences similar to those produced by the $\alpha$-subunit-deficient mice. Affected males were infertile, but developed normal male external genitalia as well as Wolffian duct derivatives (Weiss et al. 1992). Because the human LH $\beta$-subunit mutation appears to cause a complete loss of function, the different phenotypic consequences of the $\mathrm{LH}$ receptor and hormone mutation in humans could mean that there is receptor stimulation in the absence of ligand. Alternatively, another ligand such as chorionic gonadotropin may interact with the LH receptor to promote masculinization of the external genitalia in humans.

Ovaries are relatively quiescent during the fetal period. Follicular formation and estrogen production begin shortly after birth (Jones 1978; Weniger 1993). The phenotype of -1 - ovaries confirms that prenatal ovarian development does not require gonadotropin stimulation.
Remarkably, ovarian follicular development during the infantile stage also does not require gonadotropins, as follicles developed to the preantral stage in -1 - ovaries after birth. However, development of follicles to the antral stage and subsequent ovulation do require gonadotropins and estrogen. The extent of follicular development in $-/-$ mice is the same as that observed in hpg mice that lack hypothalamic stimulation of pituitary gonadotropin production (Cattanach et al. 1977). Disruption of the estrogen receptor in mice demonstrated that follicular development is limited and ovulation does not occur without estrogens; however, ovaries of the estrogen receptor null mutants contained cystic and hemorrhagic follicles not present in $\alpha$-subunit $-/$ - animals (Lubahn et al. 1993). This difference can be attributed to the deleterious effects of chronic high gonadotropin levels on the ovary (Risma et al. 1995). Females with the $\alpha$-subunit disruption, as well as some hpg females, never develop vaginal openings. Therefore, pituitary gonadotropins, acting directly or indirectly, are necessary postnatally for estrogen production, opening of the vaginal orifice, and complete maturation of follicles.

The hypothyroid phenotype in the - / - animals is similar to the phenotype of hyt mice that have a mutation in the TSH receptor (Beamer et al. 1981; Stein et al. 1994/. Both mutants exhibited retarded growth beginning $\sim 2-3$ weeks of age, arrested thyroid follicle development, and reduction of serum $\mathrm{T}_{4}$ levels. In both the hyt and $\alpha$-subunit null mutants, the appearance of the thyroid indicates that without TSH stimulation, fetal thyroid development stops $\sim$ E17 (Beamer and Cresswell 1982; Stein et al. 1989|.

\section{Altered ratios of cell types in - / - pituitaries}

The hyperplastic and hypertrophic thyrotropes are similar to the "thyroidectomy cells" seen in the pituitaries of hypothyroid animals, either congenitally hypothyroid as in the case of the hyt mouse mutant (Noguchi et al. 1986), or rendered hypothyroid as adults (Childs et al. 1981). In each of these cases, the proliferation of thyrotropes and increase in TSH $\beta$-subunit mRNA probably result from the lack of thyroid hormone feedback (for review, see Shupnik et al. 1989). These thyrotrope changes were obvious by 3 weeks of age in $-1-$ animals, suggesting that the feedback response is activated soon after birth.

The lactotropes and somatotropes are normally the most abundant cell types in the anterior pituitary gland, each comprising $30 \%-40 \%$ of the total cells. The pituitaries of $-1-$ mice were almost completely devoid of lactotropes. This could result in part from the hypogonadism and lack of gonadal steroids. PRL transcription and differentiation of lactotropes are enhanced by estrogen (Lieberman et al. 1983), and fewer lactotropes and lower pituitary PRL levels have been observed after gonadectomy and in hpg mice, respectively (Ibrahim et al. 1986; Mason et al. 1986). However, hypogonadal mice generated by gonadotrope ablation have reduced pitu- 
itary PRL content but near normal numbers of lactotropes (Kendall et al. 1991). Because the reduction in PRL is much less severe in these cases of hypogonadism, the lack of gonadal steroids probably contributes to, but does not completely explain, the almost total lack of lactotropes in $\alpha$-subunit $-/-$ animals. Although our data support the hypothesis that $\alpha$-subunit plays a role in lactotrope differentiation (Begeot et al. 1984), the impact of hypothyroidism on PRL production must still be assessed.

The reduction in somatotrope numbers in $-/-$ mice may be partially attributable to the effect of thyroid hormone on growth hormone $(\mathrm{GH}$ ) transcription (Schaufele et al. 1992). A reduction in both somatotrope number and GH mRNA levels have been observed in hyt mice and adult animals rendered hypothyroid (Surks and DeFesi 1977; Noguchi et al. 1986; Samuels et al. 1989; S.K. Kendall and S.A. Camper, unpubl.). However, the thyrotrope hyperplasia, rather than simply the lack of thyroid hormone, may have caused the reduction in number of somatotropes. Genetic dwarf mice missing TSH, GH, and PRL provide evidence that thyrotropes, somatotropes, and lactotropes are related developmentally and derive from a common cell expressing the Pit-l transcription factor (Li et al. 1990; Gage et al. 1995). In - / mice, the increase in thyrotropes was accompanied by dramatic decreases in both somatotropes and lactotropes, although the proportion of gonadotrope and corticotrope cells remained stable. This is consistent with a hypothesis that most Pit-1 precursor cells were directed toward thyrotrope differentiation at the expense of somatotropes and lactotropes.

The thyrotrope hyperplasia in 2-month-old - / - pituitaries was more advanced than that seen in pituitaries from adult mice 8 months after radiothyroidectomy. Reduction in somatotropes and lactotropes in $\alpha$-subunit $-1-$ mice also was more severe than that observed in radiothyroidectomized adult mice (data not shown). The proliferation of the thyrotropes at the expense of somatotropes and lactotropes in $-/-$ mice probably results from the availability of more undifferentiated stem cells in younger animals. The mitotic activity of differentiated thyrotropes also is much higher in immature than in mature animals (Shirasawa and Yoshimura 1982). Once differentiation has taken place, some production of thyrotropes probably occurs by recruitment or trans-differentiation of somatotropes (Horvath et al. 1990).

Progressive hypertrophy and hyperplasia of gonadotropes occurs in response to gonadectomy of both adult males and females and is reversible by steroid replacement (Ibrahim et al. 1986). However, gonadotropes in $-/-$ pituitaries did not exhibit a significant increase in size or number, consistent with the minimal effects on gonadotropes in rats or sheep gonadectomized in utero (Nakai et al. 1972; Messaoud-Toumi et al. 1993). Steroid hormone feedback on LH and FSH transcription does take place in immature animals, as increases in $\mathrm{LH}$ and FSH mRNA levels have been observed in male rats gonadectomized as young as 10 days after birth (Pakarinen and Huhtaniemi 1992). The basis for the lack of pituitary response to the hypogonadal state in $-1-$ mice is unknown.

Pituitary morphogenesis and GnRH neuron
migration in the absence of $\alpha$-subunit

We demonstrated that free $\alpha$-subunit is not required for pituitary morphogenesis, induction of hypothalamic development, or migration of GnRH neurons. Therefore, the signals necessary for mutual induction by Rathke's pouch and the hypothalamus remain elusive. Previously we have shown that $\alpha$-subunit was expressed in the extraocular and olfactory regions of the fetus at E12.5 (Kendall et al. 1994), but we noted no obvious defects in the function of these sensory organs in $-/-$ mice. Thus, expression of $\alpha$-subunit in these regions of the fetus is apparently dispensable.

Disruption of the $\alpha$-subunit gene has clarified the role of the gonadotropins and thyrotropins in development. In the mouse, LH and FSH are required after birth for gonadal maturation and genital development but not for prenatal genital development or testosterone secretion. The importance of fetal TSH in fetal thyroid follicular development was confirmed. Furthermore, the hypothyroid and hypogonadal state of the $-1-$ mice caused changes in anterior pituitary cell makeup significantly different from changes seen in pituitaries of mice rendered hypogonadal or hypothyroid as adults. These dissimilarities indicated that developing pituitaries have different plasticity and feedback responsiveness than adult pituitaries and further support the derivation of thyrotrope, somatotrope, and lactotrope cells from a common precursor cell.

\section{Materials and methods}

Construction of the targeting vector

A 4-kb HindIII fragment of the mouse glycoprotein hormone $\alpha$-subunit gene subcloned in pGEM7Zf + served as a backbone for constructing the targeting vector (Gordon et al. 1988). A 1.7-kb NotI-BamHI PGKneo fragment from the pPNT plasmid (Tybulewicz et al. 1991) was incubated with T4 polymerase to create blunt ends and ligated into a unique BalI site in exon 3 of the mouse $\alpha$-subunit gene. The resulting $8.7-\mathrm{kb}$ clone was cleaved in the polylinker at the 3 ' end of the mouse $\alpha$-subunit sequences by partial digestion with HindIII and complete digestion with EcoRI. A PGK-tk cassette, isolated from the pPNT plasmid by digestion with EcoRI and HindIII, was ligated into the $8.7-\mathrm{kb}$ clone to produce the final $11.4-\mathrm{kb}$ targeting vector. This clone was verified at the cloning junction by DNA sequencing. The targeting vector was linearized with EcoRI for transfection.

\section{Transfection and screening of ES cells}

D3 ES cells (Doetschman et al. 1985) were maintained on mouse embryonic fibroblast (MEF) feeder layers (Wurst and Joyner 1993) that were mitotically inactivated by $\gamma$-irradiation. The cells were maintained in Dulbecco's modified Eagle's medium containing $15 \%$ fetal calf serum, $0.1 \mathrm{~mm} \beta$-mercaptoethanol, and $2 \%$ leukemia inhibitory factor (LIF) (24-hr conditioned media collected from Chinese hamster ovary $(\mathrm{CHO})$ cells trans- 
fected with the LIF expression plasmid, provided by the Genetics Institute). Cells $\left(0.8 \times 10^{7}\right)$ were electroporated with $20 \mu \mathrm{g}$ DNA in $800 \mu \mathrm{l}$ of complete medium at $300 \mathrm{~V}$ and $250 \mu \mathrm{F}$ (BioRad). A total of $1.8 \times 10^{8}$ ES cells were transfected with the linearized targeting vector. Electroporated cells were immediately plated at $3.5 \times 10^{6}$ cells/plate on $5310-\mathrm{cm}$ dishes containing irradiated neo ${ }^{\mathrm{R}} \mathrm{MEF}$ feeders (Doetschman 1994). The next day, cells were renewed with ES cell medium containing $300 \mu \mathrm{g} / \mathrm{ml}$ G418. Cells were renewed every other day from this point. The media was supplemented with $2 \mu \mathrm{M}$ gancyclovir (cytovene from Syntex/from day 5 until day 12 or 13 when 880 individual colonies were picked from the plates and transferred to individual wells of 96-well plates containing irradiated neo ${ }^{\mathrm{R}} \mathrm{MEF}$ feeders. Cells were trypsinized on day 19 and split. Half of each colony was frozen at $-80^{\circ} \mathrm{C}$ on 96 -well plates in $10 \%$ dimethylsulfoxide (DMSO), and the other half was plated onto gelatincoated 96-well plates and grown for 1 week. Genomic DNA was prepared from the individual clones and analyzed by PCR (Ramírez-Solis et al. 1992). PCR-positive clones were thawed from the frozen 96-well plates and expanded for Southern analysis.

\section{Screening of G418-resistant colonies by PCR}

PCR conditions were tested on cells transfected with a control construct that contained 500 bp of mouse $\alpha$-subunit 5 ' flanking DNA sequences upstream of the $5^{\prime}$ end of the targeting vector and the neo ${ }^{\mathrm{R}}$ gene inserted into the $\mathrm{XbaI}$ site downstream of exon 3. ES cell clones containing a random integration of this construct were selected with $300 \mu \mathrm{g} / \mathrm{ml}$ of G418. PCR analysis was performed on the potential homologous recombinant clones in a 96-well thermal cycler (MJ Research, Inc.) using a forward primer from $\alpha$-subunit sequences just upstream of the HindIII site 15'-TGCCTTTTGTATTATCAGGGTACCTAGACT- $\left.3^{\prime}\right)$ and a reverse primer from the neo gene $\left(5^{\prime}\right.$-CGCCTTCTATCGCCTTCTTGACGAGTTCTT-3'). These primers yielded a product of $1.1 \mathrm{~kb}$ in homologous recombinant clones but no product if the targeting construct randomly inserted into the genome.

\section{Southern blotting}

Ten micrograms of genomic DNA were digested overnight with various restriction enzymes and Southern blots were performed as described (Kendall et al. 1994). Probes for the $5^{\prime}$ and $3^{\prime}$ ends of the mouse $\alpha$-subunit gene were prepared from $1.2-\mathrm{kb} X \mathrm{XaI}-$ BstEII and 380-bp BamHI-KpnI fragments, respectively (Fig. 1A).

\section{Generation of $\alpha$-subunit-deficient mice from ES cells}

Chromosome preparations and counts were performed on homologous recombinant ES cell clones (Robertson 1987). ES clones were injected into blastocysts from C57BL/6I mice (The Jackson Laboratory, Bar Harbor, ME) to obtain chimeras (Bradley 1987). Chimeras were bred with C57BL/6J animals to test for germ-line transmission of the agouti coat color marker. All procedures using mice were approved by the University of Michigan Committee on Use and Care of Animals. All experiments were conducted in accord with the principles and procedures outlined in the National Institutes of Health "Guidelines for the Care and Use of Experimental Animals."

\section{Screening of mice}

The presence of the disrupted allele was detected in genomic DNA prepared from tail biopsies by PCR analysis with the same primers used for ES colony screening. A second set of primers that anneal within exon $3\left(5^{\prime}\right.$-GCATATCCCACTCCCGCCAGG-3') and intron 3 (5' - CAA TTA AAGAGGATAAATGCAGGTGTCGCC- $3^{\prime}$ ) were used to detect the intact $\alpha$-subunit gene. A 220-bp fragment was amplified from the wild-type allele, but the larger fragment containing the neo insertion did not amplify from the disrupted allele. Analysis with each of these sets of primers was performed to determine the genotype of offspring of heterozygote matings.

\section{$R T-P C R$}

Pituitaries from $+1+,+1-$, and $-1-$ animals were removed, frozen immediately on dry ice, and dispersed in $1 \mathrm{ml}$ of guanidinium thiocyanate buffer using Dounce homogenizers. One microgram of RNA prepared from each homogenate (Chomczynski and Sacchi 1987) was used for cDNA synthesis with an oligo(dT) primer. PCR amplification with $\alpha$-subunit primers $\left(5^{\prime}\right.$ ATGCAGCTGTCATTCTGG-3' and 5'-GACTGCAGGATTGTACTG-3') yielded a 502-bp fragment and primers specific for TSH $\left(5^{\prime}\right.$-CTCGGATCCGTGCTTTTTGCTCTTGC-3' and 5'AAAAGCTTCCCAGATAGAAAGACTGCGG-3') produced a 394-bp fragment. Fifty-microliter PCR reactions contained cDNA equivalent to $200 \mathrm{ng}$ of RNA and 100 pmoles of each primer, and $10 \mu \mathrm{l}$ PCR reactions contained cDNA equivalent to $0.02 \mathrm{ng}$ of RNA, 0.17 pmole of each radiolabeled primer and 1.6 pmoles of each unlabeled primer. Primers were labeled with $\left[\gamma^{32} \mathrm{P} \mid \mathrm{ATP}\right.$ using T4 polynucleotide kinase for radioactive RTPCR reactions. Products were separated on $6 \%$ acrylamide gels, and gels were dried and exposed to film for $1 \mathrm{hr}$.

\section{Histology and immunohistochemistry of pituitary, gonads,} and thyroid

Testes, ovaries, thyroids, and pituitaries were removed, fixed for $2-4 \mathrm{hr}$ in $4 \%$ paraformaldehyde, embedded in paraffin, and sectioned at $3 \mu \mathrm{m}$. Sections were stained with hematoxylin and eosin. Immunohistochemistry was performed with polyclonal antisera against ovine pituitary $\alpha$-subunit $(1: 100$, no. AFP9762676), rat PRL (1:2000, no. AFP10505B), rat GH (1:1000, no. AFP411S), rat LHB (1:2000, no. AFP22238790GPOLHB), rat FSH $\beta$ (1:20, no. AFP85GP9691BFSHB), rat TSH $\beta$ (1:1000, no. AFP1274789) (National Hormone and Pituitary Program, National Institute of Diabetes and Digestive and Kidney Diseases, Bethesda, MD), and human ACTH $(1: 1000)$ (Dako, Santa Barbara, CA). Biotinylated secondary antibodies were used in conjunction with avidin and biotinylated peroxidase /Vectastain guinea pig, rabbit, and human kits, Vector Laboratories, Burlingame, CA) with diaminobenzidine as the chromogen. Normal serum was substituted for the primary antibody in negative controls. Sections were counterstained with Gill's triple strength hematoxylin (Fisher, Pittsburgh, PA).

\section{RIAs}

Free thyroxine was measured using the Ciba-Corning Automated Chemiluminescence System /Ciba-Corning Diagnostics Corp., Medfield, MA) in serum collected from six individual mice of each genotype. RIA for total testosterone was performed with a Coat-A-Count kit (Diagnostic Products Corporation, Los Angeles, CA) on serum pools from six male $+/+$ and six male -1 - mice.

\section{In situ hybridization}

In situ hybridization on frozen pituitary sections was performed as described (Kendall et al. 1994). Antisense and sense ribo- 
probes were generated from a 460-bp PstI fragment of the mouse $\alpha$-subunit cDNA cloned into the pGEM3Zf + vector (Promega, Madison, WI) (Chin et al. 1981) and a 496-bp PstI fragment of the mouse TSH $\beta$-subunit cDNA cloned into the pGEM3 vector (Chin et al. 1985). The final wash was performed in water at $65^{\circ} \mathrm{C}$ for the $\alpha$-subunit probe and in $0.1 \times \mathrm{SSC}$ at $65^{\circ} \mathrm{C}$ for the TSH $\beta$-subunit probe. Dehydrated sections were dipped in Kodak NTB-2 nuclear emulsion diluted 1:1 with water, exposed for 1 week, developed, and counterstained with cresyl violet (Sigma, St. Louis, MO).

\section{Histology and immunohistochemistry of GnRH neurons}

Six $-/$ - adult mice and six wild-type littermates were deeply anesthetized with sodium pentobarbital $(130 \mathrm{mg} / \mathrm{kg})$ and perfused through the aorta with $25 \mathrm{ml}$ of $0.1 \mathrm{M}$ sodium phosphatebuffered saline containing $0.1 \%$ sodium nitrite for vasodilation, followed by $50 \mathrm{ml}$ of $0.1 \mathrm{M}$ sodium phosphate buffer $(\mathrm{PB})$ containing $4 \%$ paraformaldehyde. Because there are no sex differences in the number or distribution of GnRH neurons (Wray and Hoffman 1986), males and females were included in each group. Brains were removed and postfixed for $1 \mathrm{hr}$ at room temperature and cryoprotected overnight in PB with $20 \%$ sucrose at $4^{\circ} \mathrm{C}$. Forty-micron coronal brain sections were cut on a cryostat and incubated free-floating in primary antiserum (LR-1, gift of Dr. Robert Benoit, Montreal General Hospital, Canada) at a dilution of $1: 10,000$ in $0.3 \%$ Triton $\mathrm{X}-100$ with $4 \%$ normal donkey serum for $24 \mathrm{hr}$ at room temperature (Silverman et al. 1986). A biotinylated secondary antibody was used in conjunction with avidin and biotinylated peroxidase (Vectastain ABC Elite Kit, Vector Laboratories) with $\mathrm{NiCl}$-enhanced 3,3' diaminobenzidine as the chromagen. Stained sections were mounted onto gelatin-coated slides.

The number of GnRH-immunoreactive neurons in every sixth section through the brain was counted and the location described using camera lucida drawings of adjacent Nisslstained sections. The total number of neurons visible in each brain and the distribution of neurons among five midline forebrain regions from $+/+$ and $-/$ - mice were compared using ANOVA. $P<0.05$ was considered significant.

\section{Acknowledgments}

We thank T. Greco, R.M. Tucker, B. England, L. Rankin, S.-I. $\mathrm{Kim}$, and $\mathrm{K}$. Brabec for their contributions to this work, D. Gordon and E.C. Ridgway for providing the mouse $\alpha$-subunit and TSH $\beta$-subunit clones, R. Benoit for the GnRH antiserum, and T. Doetschman for the D3 ES cells and neo ${ }^{R}$ mice. We also thank J. Baenziger, A.K. Christensen, R. Lloyd, J. L. Jameson, M. Matzuk, T. Magnuson, and K. Mahon for helpful discussions. We acknowledge the National Hormone and Pituitary Program, NIDDK, National Institute of Child Health and Development (NICHD) and U.S. Department of Agriculture (USDA) for providing the PRL, GH, LH $\beta$-, FSH $\beta$-, TSH $\beta$-, and $\alpha$-subunit antibodies. This work was supported by the American Cancer Society Grant DB-44A (to S.A.C.), the John and Suzanne Munn Endowed Research Fund of the University of Michigan Comprehensive Cancer Center, the University of Michigan Reproductive Sciences Center (National Institutes of Health (NIH) P30-HD 18258) Morphology core facility, and by NIH grants R01HD-30428 (S.A.C.), R01HD-32669 (R.I.W.), and PHST32HD-07274 (S.K.K.).

The publication costs of this article were defrayed in part by payment of page charges. This article must therefore be hereby marked "advertisement" in accordance with 18 USC section 1734 solely to indicate this fact.

\section{References}

Baenziger, J.U. and E.D. Green. 1991. Structure, synthesis, and function of the asparagine-linked oligosaccharides on pituitary glycoprotein hormones. In Biology of carbohydrates (ed. V. Ginsberg and P.W. Robbins), pp. 1-46. J.A.I. Press Ltd., London, UK.

Beamer, W.G. and L.A. Cresswell. 1982. Defective thyroid ontogenesis in fetal hypothyroid (hyt/hyt) mice. Anat. Rec. 202: 387-393.

Beamer, W.G., E.M. Eicher, L.J. Maltais, and J.L. Southard. 1981. Inherited primary hypothyroidism in mice. Science 212: 6163.

Begeot, M., F. Hemming, P. DuBois, Y. Combarnous, M. DuBois, and M. Aubert. 1984. Induction of pituitary lactotrope differentiation by luteinizing hormone $\alpha$ subunit. Science 226: 566-568.

Blithe, D.L., R.G. Richards, and M.C. Skarulis. 1991. Free alpha molecules from pregnancy stimulate secretion of prolactin from human decidual cells: A novel function for free alpha in pregnancy. Endocrinology 129: 2257-2259.

Bradley, A. 1987. Production and analysis of chimeric mice. In Teratocarcinomas and embryonic stem cells: A practical approach (ed. E.J. Robertson), pp. 113-152. Oxford University Press, Oxford, UK.

Cattanach, B.M., C.A. Iddon, H.M. Charlton, S.A. Chiappa, and G. Fink. 1977. Gonadotrophin-releasing hormone deficiency in a mutant mouse with hypogonadism. Nature 269: 338340.

Chen, F., Y. Wang, and D. Puett. 1993. The carboxy-terminal region of the glycoprotein hormone alph $\alpha$-subunit: Contributions to receptor binding and signaling in human chorionic gonadotropin. Mol. Endocrinol. 6: 914-919.

Childs, G.V. and D.G. Ellison. 1980. An immunocytochemists's view of gonadotropin storage in the adult male rat: Cytochemical and morphological heterogeneity in serially sectioned gonadotropes. Am. J. Anat. 158: 397-409.

Childs, G.V., H.-Y. Yang, R.B. Tobin, J.F. Wilber, and M. Kubeck. 1981. Effects of thyroidectomy, propylthiouracil, and thyroxine on pituitary content and immunocytochemical staining of thyrotropin (TSH) and thyrotropin releasing hormone (TRH). I. Histochem. Cytochem. 29: 357-363.

Chin, W.W., H.M. Kronenberg, P.C. Dee, F. Maloof, and J.F. Habener. 1981. Nucleotide sequence of the mRNA encoding the pre- $\alpha$-subunit of mouse thyrotropin. Proc. Natl. Acad. Sci. 78: 5329-5333.

Chin, W.W., M.A. Shupnik, D.S. Ross, J.F. Habener, and E.C. Ridgway. 1985. Regulation of the $\alpha$ and thyrotropin $\beta$-subunit messenger ribonucleic acids by thyroid hormones. Endocrinology 116: 873-878.

Chomczynski, P. and N. Sacchi. 1987. Single-step method of RNA isolation by acid guanidinium thiocyanate-phenolchloroform extraction. Anal. Biochem. 162: 156-159.

Corless, C.L., M.M. Matzuk, T.V. Ramabhadran, A. Krichevsky, and I. Boime. 1987. Gonadotropin beta subunits determine the rate of assembly and the oligosaccharide processing of hormone dimer in transfected cells. J. Cell Biol. 104: 11731181.

Daikoku, S., M. Chikamori, T. Adachi, and Y. Maki. 1982. Effect of the basal diencephalon on the development of Rathke's pouch in rats: A study in combined organ cultures. Dev. Biol. 90: 198-202. 
Daikoku, S., M. Chikamori, T. Adachi, Y. Okamura, T. Nishiyama, and Y. Tsuruo. 1983. Ontogenesis of hypothalamic immunoreactive ACTH cells in vivo and in vitro: Role of Rathke's pouch. Dev. Biol. 97: 81-88.

Desjardins, C. 1981. Endocrine signalling and male reproduction. Biol. Reprod. 24: 1-21.

Doetschman, T. 1994. Gene transfer in embryonic stem cells. In Transgenic animal technology: A laboratory handbook (ed. C. Pickert), pp. 115-146. Academic Press, San Diego, CA.

Doetschman, T.C., H. Eistetter, M. Katz, W. Schmidt, and R.J. Kemler. 1985. The in vitro development of blastocyst-derived embryonic stem cell lines: Formation of visceral yolk sac, blood islands and myocardium. J. Embryol. Exp. Morphol. 87: 27-45.

Gage, P.J., A.C. Lossie, L.M. Scarlett, R.V. Lloyd, and S.A. Camper. 1995. Ames dwarf mice exhibit somatotrope commitment but lack growth hormone-releasing factor response. Endocrinology 136: 1161-1167.

Gordon, D.F., W.M. Wood, and E.C. Ridgway. 1988. Organization and nucleotide sequence of the mouse alpha-subunit gene of the pituitary glycoprotein hormones. DNA 7:679690.

Hamilton, W.J. and H.W. Mossman. 1972. Human embryology: Prenatal development of form and function, 4th ed. Williams \& Wilkins, Baltimore, MD.

Hoffman, G.E., K.M. Knigge, J.A. Moynihan, V. Melnyk, and A. Arimura. 1978. Neuronal fields containing luteinizing hormone releasing hormone (LHRH) in mouse brain. Neuroscience 3: 219-231.

Horvath, E., R.V. Lloyd, and K. Kovacs. 1990. Propylthiouracylinduced hypothyroidism results in reversible transdifferentiation of somatotrophs into thyroidectomy cells. Lab Invest. 63: 511-520.

Ibrahim, S.N., S.M. Moussa, and G.V. Childs. 1986. Morphometric studies of rat anterior pituitary cells after gonadectomy: Correlation of changes of gonadotropes with the serum levels of gonadotropins. Endocrinology 119: 629-637.

Japon, M.A., M. Rubinstein, and M.J. Low. 1994. In situ hybridization analysis of anterior pituitary hormone gene expression during fetal mouse development. I. Histochem. Cytochem. 42: 1117-1125.

Jones, R.E. 1978. The vertebrate ovary. Plenum Press, New York.

Keene, J.L., M.M. Matzuk, T. Otani, B.C. Fauser, A.B. Galway, A.J. Hsueh, and I. Boime. 1989. Expression of biologically active human follitropin in Chinese hamster ovary cells. $J$. Biol. Chem. 264: 4769-4775.

Kendall, S.K., T.L. Saunders, L. Jin, R.V. Lloyd, L.M. Glode, T.M. Nett, R.A. Keri, J.H. Nilson, and S.A. Camper. 1991. Targeted ablation of pituitary gonadotropes in transgenic mice. Mol. Endocrinol. 5: 2025-2036.

Kendall, S.K., D.F. Gordon, T.S. Birkmeier, D. Petrey, V.D. Sarapura, K.S. O'Shea, W.M. Wood, R.V. Lloyd, E.C. Ridgway, and S.A. Camper. 1994. Enhancer-mediated high level expression of mouse pituitary glycoprotein hormone $\alpha$-subunit transgene in thyrotropes, gonadotropes, and developing pituitary gland. Mol. Endocrinol. 8: 1420-1433.

Kremer, H., R. Kraaij, S.P.A. Toledo, M. Post, J.B. Fridman, C.Y. Hayashida, M. van Reen, E. Milgrom, H.-H. Ropers, E. Mariman, A.P.N. Themmen, and H.G. Brunner. 1995. Male pseudohermaphroditism due to a homozygous missense mutation of the luteinizing hormone receptor gene. Nature Genet. 9: 160-164.

Lapthorn, A.J., D.C. Harris, A. Littlejohn, J.W. Lustbader, R.E. Canfield, K.J. Machin, F.J. Morgan, and N.W. Isaacs. 1994. Crystal structure of human chorionic gonadotropin. Nature
369: 455-461.

Li, S., E.B. Crenshaw III, E.J. Rawson, D.M. Simmons, L.W. Swanson, and M.G. Rosenfeld. 1990. Dwarf locus mutants lacking three pituitary cell types result from mutations in the POU-domain gene Pit-1. Nature 347: 528-533.

Lieberman, M.E., M.B. Slabaugh, J.J. Rutledge, and J. Gorski. 1983. The role of estrogen in the differentiation of prolactin producing cells. I. Steroid Biochem. 19: 275-281.

Lubahn, D.B., J.S. Moyer, T.S. Golding, J.F. Couse, K.S. Korach, and O. Smithies. 1993. Alteration of reproductive function but not prenatal sexual development after insertional disruption of the mouse estrogen receptor gene. Proc. Natl. Acad. Sci. 90: 11162-11166.

Mason, A.J., S.L. Pitts, K. Nikolics, E. Szonyi, J.N. Wilcox, P.H. Seeburg, and T.A. Stewart. 1986. The hypogonadal mouse: Reproductive functions restored by gene therapy. Science 234: 1372-1378.

Matzuk, M.M., C.M. Kornmeier, G.K. Whitfield, I.A. Kourides, and I. Boime. 1988. The glycoprotein alpha-subunit is critical for secretion and stability of the human thyrotropin betasubunit. Mol. Endocrinol. 2: 95-100.

Matzuk, M.M., M.M. Spangler, M. Camel, N. Suganuma, and I. Boime. 1989. Mutagenesis and chimeric genes define determinants in the beta subunits of human chorionic gonadotropin and lutropin for secretion and assembly. I. Cell Biol. 109: 1429-1438.

Messaoud-Toumi, L.H., C. Taragnat, and P. Durand. 1993. Castration effects on the gonadotrope cell populations of the fetal sheep pituitary in late gestation. Neuroendocrinology 58: 548-554.

Nakai, T., Y. Eguchi, S. Sakamoto, and T. Kigawa. 1972. Sex difference in development of fetal pituitary-gonadal axis: Histologic observations on the anterior pituitary in fetal rats gonadectomized in utero. Endocrinol. Ipn. 19: 483-487.

Noguchi, T., M. Kudo, T. Sugisaki, and I. Satoh. 1986. An immunocytochemical and electron microscopic study of the hyt mouse anterior pituitary gland. I. Endocrinol. 109: 163168.

Pakarinen, P. and I. Huhtaniemi. 1992. Age-related discrepancies between serum and pituitary gonadotrophin, and pituitary gonadotrophin subunit mRNA responses to castration and testosterone replacement in male rats. I. Endocrinol. 135: 507-515.

Pelletier, G., R. Leclerc, and F. Labrie. 1976. Identification of gonadotropic cells in the human pituitary by immunoperoxidase technique. Mol. Cell Endocrinol. 6: 123-128.

Price, D. and E. Ortiz. 1965. The role of fetal androgen in sex differentiation in mammals. In Organogenesis (ed. R.L. DeHaan and H. Ursprung), pp. 629-652, Holt, Rinehart \& Winston, New York.

Ramírez-Solis, R., J. Rivera-Pérez, J.D. Wallace, M. Wims, H. Zheng, and A. Bradley. 1992. Genomic DNA microextraction: A method to screen numerous samples. Anal. Biochem. 201: 331-335.

Risma, K.A., C.M. Clay, T.M. Nett, J. Yun, and J.H. Nilson. 1995. Targeted overexpression of luteinizing hormone in transgenic mice leads to infertility, polycystic ovaries, and ovarian tumors. Proc. Natl. Acad. Sci. 92: 1322-1326.

Robertson, E.J. 1987. Embryo-derived stem cell lines. In Teratocarcinomas and embryonic stem cells: A practical ap. proach (ed. E.J. Robertson), pp. 71-112. Oxford University Press, Oxford, UK.

Samuels, M.H., M.E. Wierman, C. Wang, and E.C. Ridgway. 1989. The effect of altered thyroid status on pituitary hormone messenger ribonucleic acid concentrations in the rat. Endocrinology 124: 2277-2282. 
Schaufele, F., B.L. West, and J.D. Baxter. 1992. Synergistic activation of the rat growth hormone promoter by Pit-1 and the thyroid hormone receptor. Mol. Endocrinol. 6: 656-665.

Schwanzel-Fukuda, M., K.L. Jorgenson, H.T. Bergen, G.D. Weesner, and D.W. Pfaff. 1992. Biology of normal luteinizing hormone-releasing hormone neurons during and after their migration from olfactory placode. Endocrine Rev. 13: 623634.

Schwind, J.L. 1928. The development of the hypophysis cerebri of the albino rat. Am. J. Anat. 41: 295-315.

Shirasawa, N. and F. Yoshimura. 1982. Immunohistochemical and electron microscopical studies of mitotic adenohypophysial cells in different ages of rats. Anat. Embryol. 165: 51-61.

Shupnik, M.A., E.C. Ridgway, and W.W. Chin. 1989. Molecular biology of thyrotropin. Endocrine Rev. 10: 459-475.

Silverman, A.J., E.A. Zimmerman, G.J. Kokoris, and M.J. Gibson. 1986. Ultrastructure of gonadotropin-releasing hormone neuronal structures derived from normal fetal preoptic areas and transplanted into hypogonadal mutant $(\mathrm{hpg})$ mice. I. Neurosci. 6: 2090-2096.

Simmons, D.M., J.W. Voss, H.A. Ingraham, J.M. Holloway, R.S. Broide, M.G. Rosenfeld, and L.W. Swanson. 1990. Pituitary cell phenotypes involve cell-specific Pit-1 mRNA translation and synergistic interactions with other classes of transcription factors. Genes \& Dev. 4: 695-711.

Stein, S.A., D.R. Shanklin, L. Krulich, M.G. Roth, C.M. Chubb, and P.M. Adams. 1989. Evaluation and characterization of the hyt/hyt hypothyroid mouse. II. Abnormalities of TSH and the thyroid gland. Neuroendocrinol. 49: 509-519.

Stein, S.A., E.L. Oates, C.R. Hall, R.M. Grumbles, L.M. Fernandez, N.A. Taylor, D. Puett, and S. Jin. 1994. Identification of a point mutation in the thyrotropin receptor of the hyt/hyt hypothyroid mouse. Mol. Endocrinol. 8: 129-138.

Surks, M.I. and C.R. DeFesi. 1977. Determination of the cell number of each cell type in the anterior pituitary of euthyroid and hypothyroid rats. Endocrinology 101: 946-958.

Tybulewicz, V.L., C.E. Crawford, P.K. Jackson, R.T. Bronson, and R.C. Mulligan. 1991. Neonatal lethality and lymphopenia in mice with a homozygous disruption of the $\mathrm{c}$-abl protooncogene. Cell 65: 1153-1163.

Weiss, J., L. Axelrod, R.W. Whitcomb, P.E. Harris, W.F. Crowley, and J.L. Jameson. 1992. Hypogonadism caused by a single amino acid substitution in the $\beta$-subunit of luteinizing hormone. N. Engl. J. Med. 326: 179-183.

Weniger, J.-P. 1993. Estrogen production by fetal rat gonads. $J$. Steroid. Mol. Biol. 44: 459-462.

Wray, A. and G.E. Hoffman. 1986. Postnatal morphological changes in rat LH-RH neurons correlated with sexual maturation. Neuroendocrinology 43: 93-97.

Wray, S., B.H. Gahwiler, and H. Gainer. 1988. Slice cultures of LHRH neurons in the presence and absence of brainstem and pituitary. Peptides 9: 1151-1175.

Wray, S., A. Nieburgs, and S. Elkabes. 1989. Spatiotemporal cell expression of luteinizing hormone-releasing hormone in the prenatal mouse: Evidence for an embryonic origin in the olfactory placode. Dev. Brain Res. 46: 309-318.

Wurst, W. and A.L. Joyner. 1993. Production of targeted embryonic stem cells clones. In Gene targeting: A practical approach (ed. A. L. Joyner), pp. 36-38. Oxford University Press, Oxford, UK.

Xia, H., F. Chen, and D. Puett. 1994. A region in the human glycoprotein hormone alpha-subunit important in holoprotein formation and receptor binding. Endocrinology 134: 1768-1770. 


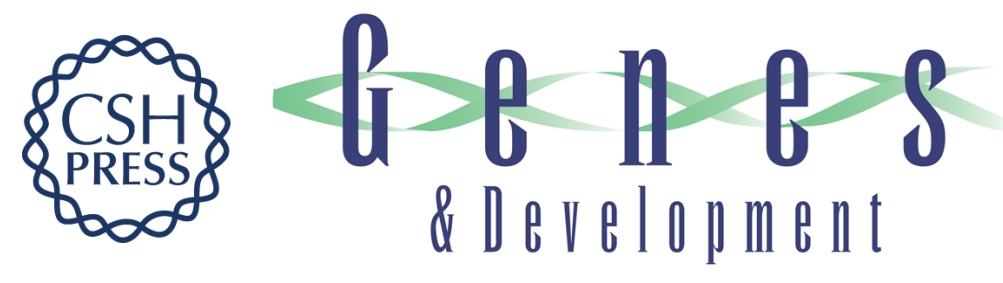

\section{Targeted disruption of the pituitary glycoprotein hormone alpha-subunit produces hypogonadal and hypothyroid mice.}

S K Kendall, L C Samuelson, T L Saunders, et al.

Genes Dev. 1995, 9:

Access the most recent version at doi:10.1101/gad.9.16.2007

References This article cites 58 articles, 13 of which can be accessed free at:

http://genesdev.cshlp.org/content/9/16/2007.full.html\#ref-list-1

License

Email Alerting Receive free email alerts when new articles cite this article - sign up in the box at the top Service right corner of the article or click here.

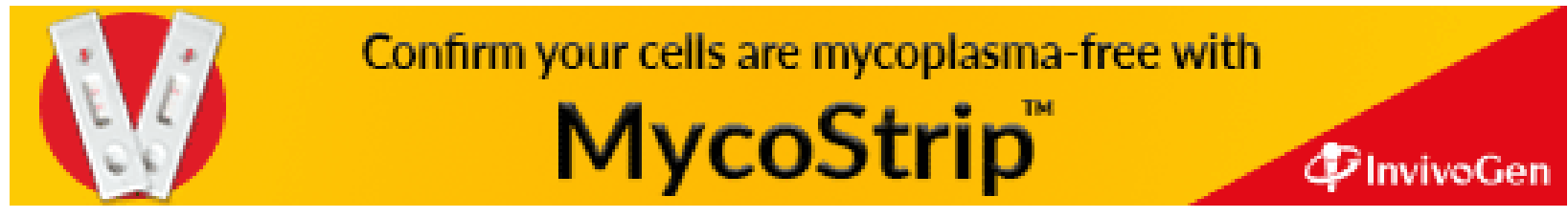

